\title{
Internal Labor Markets and Earnings Trajectories in the Post-Fordist Economy: An Analysis of Recent Trends
}

\author{
Thomas A. DiPrete \\ Duke University \\ Dominique Goux \\ INSEE, Paris, France
}

and

\section{Eric Maurin}

CREST, Paris, France

Published online January 23, 2002

\begin{abstract}
The evolution of the "post-Fordist" economy is alleged to have changed the structure of work careers in the American work force of the 1990s. Most scholarly attention has focused on the implications of post-Fordism for job mobility or for the fraction of the workforce that has a "contingent" employment relationship with the employer. But post-Fordism should also affect the relationship between job rewards and tenure with the employer, which sociologists have recognized as a core characteristic of the firm internal labor market. The theory of post-Fordism predicts a weaker relationship between tenure and job rewards and a correspondingly stronger relationship between general labor force experience and job rewards for the highly educated workers that arguably have become an even more dominant source of value creation in the post-Fordist economy. Analyses of trend data for male workers from the Current Population Surveys for the years 1983-1998 largely support these hypotheses. Additional analyses suggest that observed trends in the returns to job tenure and experience arise from real changes in the production of value rather than from selection mechanisms linked to post-Fordist-induced trends in the

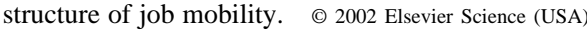

Results in this article were previously presented at the 1999 Annual Meetings of the American Sociological Association, August 8, Chicago (IL) and at the Labor Markets Colloquium at the Max Planck Institute for Human Development in Berlin. This research has been supported in part by UNC-Duke European Center Grant 5-49672. We thank two anonymous reviewers for their helpful comments on an earlier draft of this article. 
The economies of advanced industrial societies have been moving away from the mass-production "Fordist" model of the firm in favor of a more dynamic model organized along "post-Fordist" lines. This assertion has been a recurring theme in recent economic sociology (Piore and Sabel, 1984; Block, 1990; Osterman, 1994; Burris, 1998) and moreover has potentially important consequences for social stratification. While there is no single accepted theory of the "post-Fordist" economy, most accounts emphasize two complementary aspects: (1) greater internal flexibility achieved through the flattening of organizational hierarchies, the use of new technologies, and so on; and (2) increased reliance on the external market (often through various forms of relational contracting) for goods, services, and skills, which are then combined with internal competencies to form products. The product of these two trends is the increasing predominance of weblike organizations in contrast to the pyramidal form that typified Fordist firms.

The hypothesized shift to post-Fordist production arguably has several important consequences not only for the structure of firms and the organization of the economy but also for employment relationships and work careers. Perhaps most notably, post-Fordism is asserted to have caused the "devolution" of the internal labor market that was the centerpiece of the employment relationship in organizations structured along Fordist principles (Noyelle, 1987). Many scholars have argued that this "devolution" has caused the "externalizing" of work careers and in the process has generated (1) a loss of job security and consequently higher rates of worker displacement; (2) a greater use of "contingent" workers, who have low job security; and (3) higher levels of job mobility as a consequence of the presumably greater rates of job creation and job destruction in the postFordist economy.

It is indisputable that the occupational distribution has shifted in recent years in a direction that is consistent with post-Fordist theory (DiPrete and Forristal, 1995). A decline in the number of blue-collar factory jobs has been associated with a reduction in pay for workers with high school or lower education that has contributed to growing earnings inequality in the United States (Morris and Western, 1999). It is also indisputable that the restructuring of the 1980s and early 1990s displaced a large number of workers. Production workers experienced the brunt of this displacement early on, though by the early 1990s, workers in professional and managerial jobs were also experiencing higher levels of job insecurity (Gardner, 1995; Fallick, 1996).

The validity of other well-publicized post-Fordist hypotheses, however, is less clear. Time-series evidence suggests that the proportion of workers who are part time has increased (Tilly, 1996), though most of this increase is due to the increased proportion of workers who are women. ${ }^{1}$ The proportion of temporary workers has also increased (Golden and Appelbaum, 1992; Golden, 1996), and

${ }^{1}$ There is no upward trend in part-time work among women, while the percentage of men working part time has increased from 8.4 to $12.4 \%$ from the late 1960s to 1996 (Blank, 1998). 
other indicators provide some support for the general proposition that contingent work is growing as a proportion of all employment (Rosenfeld, 2001; Kalleberg, Reskin, and Hudson, 2000). However, the more abstract question of whether the proportion of "contingent workers" has increased over time is complicated both by a lack of clarity in the definition of contingent work and by a lack of comparable trend data. The core idea of contingent workforce status is the lack of job security, which is a difficult concept to operationalize ex ante because American workers do not have labor contracts that provide them with legal security guarantees.

Furthermore, it is perhaps underappreciated in sociology that recent studies of the distribution of job tenure in the American workforce generally fail to confirm any decisive shift in the level of job security in the American workforce. While McGill et al. (1996) found that median years of tenure for men in the current job was higher in 1991 than in 1966, Diebold, Neumark, and Polsky (1997) found "approximate stability" of retention rates from the early 1980s to the early 1990s. Farber (1996) found some increase in job loss during the 1990s, Jaeger and Stevens (1998) found a slight increase in the fraction of male workers overage 30 with fewer than 10 years of tenure beginning in the early 1990s, while Gottschalk and Moffitt (1998) found no evidence of a trend toward lower job stability from the 1980s to the 1990s. There is a lot of mobility in the American labor market, but this has always been true. Thus, even though the organizational evidence for what might be called the post-Fordist trend is reasonably compelling (Osterman, 1994), the definitive identification of a particularly "post-Fordist" component of job mobility has not yet appeared in the scholarly literature. In short, the evidence for a post-Fordist-induced change in the structure of work careers is suggestive, but not yet definitive.

The existing literature, however, fails to identify the full range of career consequences that arguably follow from the post-Fordist thesis. The externalization of employment relations should have an impact not only on the crosssectional distribution of employment relations (e.g., the percentage of workers on temporary contracts) or on the duration of the job spell before displacement or voluntary mobility. It should also affect the structure of earnings trajectories and the relative influence of internal and external processes on these wage trajectories. The structure of earnings trajectories is a fundamental issue in the study of careers; indeed, the presumption of comparatively modest starting salaries coupled with steady increases until midlife were defining characteristics that distinguished a "career" from an ordinary "job" in common parlance for much of the century. In this article, therefore, we focus not on the end point of the employment relationship, but rather on the wage profiles near the starting point. Specifically, we address the question of whether post-Fordism has led to increased job rewards at the start of the employment relationship relative to the prevalent pattern that existed in the Fordist economy.

To show how this hypothesis derives from post-Fordist theory, it is useful to return to the theory of internal markets as developed by Doeringer and Piore 
(1971) and later elaborated by Althauser and Kalleberg. In their 1981 article on "Firms, Occupations and the Structure of Labor Markets: A Conceptual Analysis," Althauser and Kalleberg argued that internal labor markets had effects beyond the simple provision of job security. In addition, an internal labor market structured the career around a job ladder and produced "movement up the ladder associated with a progressive development of knowledge or skill." Althauser and Kalleberg argued that the knowledge in question was firm-specific knowledge in the case of "firm internal labor markets" and occupation-specific knowledge in the case of "occupational internal labor markets." Underlying this model of the career was the presumption that each firm had (at least to some extent) a specific form of production, that workers who were trained in these specific methods were more valuable, and that these workers were rewarded for their increased value through regular advancement and/or regular wage and salary increases. Internal advancement had the side benefit of protecting the firm's investment in its workforce by creating disincentives for workers to leave the firm.

This distinction between the "internal" and the "external" market, while a useful conceptualization, can easily become too reified. DiPrete and McManus (1993) argued that many jobs are simultaneously situated within firm and within occupational internal labor markets. Using data for the 1980s, they showed that workers in these "compound labor markets" received higher rewards on account of both their accumulated experience within their occupation and their tenure within the firm. Thus, during the 1980s (and perhaps even earlier), organizationspecific experience may have been oversold as the basis for progressive development of knowledge or skill.

Post-Fordism has arguably further undermined the specificity of production within firms because much of post-Fordist production takes place across organizational boundaries, which themselves are shifting continually as firms and workers come together in fluid combinations in order to bring products to market. Reich (1991) argued that it was precisely this recombination of production factors that was the source of much of the "value-added" in post-Fordist production. In Reich's version of the post-Fordist model, value-added in the postFordist world stems not so much from capital and routine labor as from the activities of what he called "symbolic analysts." Reich argued that symbolic analysts serve three primary functions. Some are "problem-solvers." Others are "problem-identifiers." A third group consists of the "strategic brokers," who bring the "problem-identifiers" and the "problem-solvers" together in order to develop marketable services and products. These three groups of workers, according to Reich's model, capture an increasing share of total value-added in the form of salary, bonuses, equity participation, consulting fees, and other forms of compensation. They become more valuable as they gain experience. But this experience is not situated within the boundaries of firms. Indeed, it is the essential nature of post-Fordist production that teams of symbolic analysts can be formed within existing organizations, across organizations, or in new organizations purposely created to pursue a particular project. Reich argues that the 
potential mobility of problem-solvers, problem identifiers, and strategic brokers is a major risk in the post-Fordist world for companies that attempt to achieve success through acquisition of other companies because the "value" of their acquisition may dissipate as newly "bought" workers chose to leave for other jobs.

If value-added in a post-Fordist world increasingly arises from the recombining of human skills in new ways, then the old formula for value-the gradual acquisition of firm-specific skills-arguably becomes obsolete. It may be precisely the rapidity of skillful recombination of talented workers and capital that creates value in the post-Fordist economy. In a highly turbulent marketplace, windows of opportunity remain open only briefly before a competitor with more efficient production methods gains control of the market or technological change erodes the value of the potential good or service.

Taken literally, the post-Fordist model is really a model of team production rather than individual production. Instead of growing more valuable with firmspecific experience, teams may grow less valuable over time as their vigor and appropriateness to market conditions diminishes. In many cases, of course, the decay arises because the hoped for innovation did not work out (the potential value was never realized). But even in cases where value is produced, the post-Fordist model predicts a relatively high rate of obsolescence, which creates a steady pressure for reorganization either within the boundaries of the firm or through a restructuring of those boundaries. Instead of a liability of newness (a common theme in the organizations literature), the post-Fordist model asserts a liability of stagnation for teams and their associated work processes.

The post-Fordist model has important implications for career trajectories. It suggests that, for at least some members of a work team, it is their very freshness, their lack of tenure in the organization that makes them valuable. To put it another way, a worker's value to a post-Fordist firm may derive primarily from substantive skills and experience in the occupation prior to joining the firm. In the competitive market that characterizes post-Fordist economies, this change in the determinants of productivity should produce a change in the determinants of earnings. Instead of a pattern of steadily rising wages within the firm, diminished voluntary interfirm mobility at higher tenure levels, and significant average wage losses for those who involuntarily change employers, a greater share of wage gains under post-Fordism comes from general experience, which is valuable to other firms as well as the home firm. Furthermore, these wage gains may be realized not so much from a steady stream of burcaucratically determined increases as from large wage gains associated with mobility within firms or from mobility between firms that is associated with the reconfiguration of team production. According to this model, talented workers can jump from firm to firm to take advantage of a better "match" in the ever-changing market without paying a heavy price through the loss of valuable firm-specific experience.

This "value-of-production"-based theory of wage trajectories in post-Fordist firms implies the following hypotheses: 
Hypothesis 1: Wage-tenure profiles are flatter in post-Fordist than in Fordist organizations. Hypothesis 2: Prefirm experience is relatively more valuable in post-Fordist than in Fordist organizations.

The theory of post-Fordism does not imply that the economy can be sharply divided into those firms which are "post-Fordist" and those which are not. Instead, it suggests that post-Fordist techniques have been diffusing throughout the American economy as the spread of technology (particularly information technology) makes this form practical and profitable across a growing spectrum of firms. At any point in time during this transformation, the diffusion is incomplete. Some firms will be relatively further along this diffusion path than others. There will also be heterogeneity within firms, which may be more "post-Fordist" in some departments and less post-Fordist in others (Osterman, 1994).

We therefore search for evidence of this diffusion in its impact on wage trajectories. For practical reasons, we remain at the industry level in our evaluation of the above hypotheses. We do so for the simple reason that no data exist that would provide usable information on the specific "Fordist" or "post-Fordist" character of individual organizations while at the same time providing adequate sample size and sufficient information on wage trajectories to permit the estimation of the appropriate wage equations. Instead, we make two kinds of comparisons that enable us to test our hypotheses. First, because many commentators agree that post-Fordism has been more common in the dynamic industries that tend to use high-technology production processes and relatively highly skilled work forces (Kanter, 1984,1991; Hodson, 1988; Osterman, 1994), we make a comparison between high-technology and other industries. Second, because it is generally thought that post-Fordist techniques have been diffusing through the American economy, we perform a trend analysis across all American industries. In performing both analyses, we fully recognize that the comparison groups are heterogeneous. While most high-technology firms probably employ post-Fordist technology, it is certainly not true that all firms outside of the high-technology sector employ Fordist technology. However, this fact does not undercut our analytical strategy. All we require is that firms in high-technology industries be more likely to use post-Fordist techniques than firms outside this sector. This average difference in production techniques will imply a difference in the estimated coefficients of the wage equations for the two sectors. Similarly, our trend analysis strategy does not require that no firms be post-Fordist at one point in time, while all firms be post-Fordist at a later point in time. It only requires that the proportion of firms using post-Fordist techniques increases over time. It is the statistical results themselves that provide the ultimate test of the adequacy of industry-level data for "seeing" the impact of post-Fordist diffusion on wage trajectories. Our hypotheses can be restated at the industry level as follows: 
Hypothesis 1 (respecified): Wage-tenure profiles are flatter in high-technology industries than in other industries.

Hypothesis 2 (respecified): Prefirm experience is relatively more valuable in high-technology industries than in other industries.

Hypothesis 3: Wage-tenure profiles have become flatter during the 1990s than they were previously.

Next, we address the question of the skill sector of the labor market that would be most affected by the post-Fordist transformation. The literature on postFordism makes a sharp distinction between the situation of highly skilled workers and routine workers. Highly skilled workers are presumed to gain greater market power from the emergence of a post-Fordist market structure. Highly skilled workers can, in effect, rent their problem-solving, problemidentifying, or strategic brokering skills to their present employer, or to a different employer, or they can charge a fee for their services as an independent contractor. The value of these skills stems increasingly from their education and general labor market experience rather than from their tenure with a specific employer. The situation for routine workers is sharply different. The skills of routine workers are not advantaged by the technological changes underlying the emergence of the post-Fordist economy. On the contrary, routine workers are presumed to lose at least to some extent the benefits that came from Fordist internal labor markets, namely employment stability and steadily rising wages until midcareer. Ironically, the conceptually quite different situations of highly skilled and more routine workers lead to the same prediction for both groups, namely that returns to tenure with the firm decline under post-Fordism. The principal difference in the trends for high-skilled workers and routine workers concerns baseline earnings differences and the value of general experience. The rising market value of education implies that the highly educated have increasingly greater baseline earnings, and their earnings gain from general labor market experience should increase relative to less well educated workers. Because the rise in education-based differences in average earnings is well documented in the literature (Johnson, 1997; Lerman, 1997), we do not formulate this prediction as a hypothesis. We state our expectations concerning the value of general experience as follows:

Hypothesis 4: General (prefirm) labor force experience has become more valuable in the 1990s for workers with high levels of education than it was previously.

Finally, we expect our results to vary with age. The compensation of older workers is affected not only by current conditions but also by conditions from the past that affected their early compensation and mobility history. In contrast, the compensation of younger workers is relatively more sensitive to current labor market conditions. For this reason, we expect the following: 
Hypothesis 5: The influence of post-Fordist forces on earnings returns to tenure and to general labor force experience should be stronger for younger workers than for older workers.

\section{METHODS AND DATA}

We test our post-Fordist theory of wage profiles theory using data from the Current Population Survey (CPS). The CPS data have two important advantages for our study. First, they provide coverage of the relevant historical period. Second, they provide large enough sample sizes so that important trends are measurable at statistically significant levels. We draw our sample from the January 1983, 1987, and 1991 CPSs and from the February 1996 and 1998 CPSs because for this set of surveys the U.S. Census Bureau collected data on tenure with the current employer. We restrict our analysis to the $25 \%$ of the sample in these surveys who were also asked to provide wage and salary information.

In order to test our hypotheses, we estimated three sets of equations. First, we estimated separate models for workers in the high-technology industry sector and for workers in other industries. Second, we analyzed the trend in the effects of tenure and general labor force experience between the early 1980s and the late 1990s. Third, we estimated trends using models that correct for possible selection bias as described later in the article.

We based our operationalization of the high-technology sector on the definition proposed by Hadlock, Hecker, and Gannon (1991) and later also used by Luker and Lyons (1997). We translated the standard industrial classification (SIC) codes used in their definition into 1980 and 1990 three-digit census industry codes, which is the native coding scheme employed in the CPS. In both our sector analysis and in our trend analysis, we estimated separate models for workers with 16 or more years of education and for less well-educated workers. ${ }^{2}$ To test our hypothesis about age effects, we separated the workers age 35 or younger from workers between 35 and 55 years of age. In order to avoid problems associated with the transition to retirement, we excluded workers older than age 55 from our analysis. We further limited our analysis to wage and salary workers who usually work 35 or more hours a week.

Because of its relatively large sample sizes and reasonably comparable measures over the past 2 decades, the CPS provides a sound basis for testing our hypotheses. The CPS, of course, lacks direct measures of labor force experience. A large literature, especially though not exclusively in labor economics, supports the assertion that male experience can be imputed using the now-conventional formula of age minus years of completed education minus 5. It is also well known that such an imputation overstates the experience of women who have had discontinuous careers. This overstatement is a particular problem for testing our

\footnotetext{
${ }^{2}$ The education questions were changed in the 1994 CPS. From 1996 on we used self-reports of having completed a 4-year college degree as the basis for classifying individuals as having completed college or not.
} 
hypotheses on data for women. Because the average labor force experience of women has been increasing over time, the bias in the experience coefficient for women also has a trend to it. Because the data do not allow us to distinguish between a trend in the coefficients for women from a trend in the bias in the wage equation for women, we restrict our analysis to men.

In analyzing earnings trends using the CPS even for male workers, there are two additional technical issues that must be considered. The first is the redesign of CPS questions and method of data collection that occurred in 1994, as well as the introduction of new weights derived from the 1990 census. The second is the time-varying top-code used in the collection of earnings data in the CPS. In 1993, the census collected data using both the old and the new form of the CPS in order to assess the impact of the redesign. Researchers have found no significant differences for men arising from these design changes when the same top-codes are employed for both surveys (Polivka, 1996; see also Ryscavage, 1995; Bernstein and Mishel, 1997). A potentially more serious change concerns the time-varying top-codes found in CPS data. CPS top-codes were occasionally changed over the period covered by our analysis, mostly notably in 1994, when a new system was put in place for computing top-codes in the CPS. Because of inflation, however, the effective top code actually varies from year to year. The problem of time-varying top-codes is potentially quite serious for a trend analysis. Analytical techniques which treat these top-codes as valid earnings reports might erroneously report the existence or nonexistence of trends, when in reality the results are due purely to the changes in the top-codes over time. While scholars often deal with categorical earnings data by assigning midpoints to the categories, this strategy is not feasible in the case of top-codes because the top category is open-ended. ${ }^{3}$ Tobit analysis is the usual technique employed for censored data where there is a single censoring point (e.g., a single top-code in the data). To deal with the problem of time-varying top-codes, we estimated regression models using censored normal regression (CNR), which is a generalization of Tobit analysis that was introduced by Amemiya (1973) and that allows the censoring threshold (i.e., the value above which only the top-code for earnings is reported) to vary across the observations in a sample.

We performed censored normal regression after we first converted the earnings to constant dollars using a CPI deflator and then converted the result to the natural logarithm. As covariates in our regression analyses we used the following measures: (1) dummy variables for metropolitan area status (central city within metropolitan statistical area, outside central city but within MSA, not in MSA, or not identified); (2) potential labor force experience (measured as age-education-5; note that in addition we divided our sample on the basis of age as described above); (3) dummy variables for each yearly cohort; (4) tenure with the

${ }^{3}$ The strategy of simply assigning "sensible" values to the top-coded cases is unattractive. These assignments may appear reasonable, but they are still arbitrary and this assignment process itself may induce a trend in the estimates where none exists in reality or suppress estimates of a real trend. 
TABLE 1

Effects of Tenure and Experience High-Technology vs Other Industries for U.S. Male Full-Time Workers, Censored Normal Regression Model

Age $\leq 35$, Not Age $\leq 35$, High- $35<$ Age $\leq 55$, Not $35<$ Age $\leq 55$ High-Technology Technology High-Technology High-Technology

\begin{tabular}{|c|c|c|c|c|}
\hline \multicolumn{5}{|c|}{ Workers with at least 16 years of education } \\
\hline Tenure $\leq 2$ years & $\begin{array}{l}-0.106 \\
(4.81)^{* *}\end{array}$ & $\begin{array}{c}-0.069 \\
(1.81)^{*}\end{array}$ & $\begin{array}{l}-0.137 \dagger \\
(4.57)^{* *}\end{array}$ & $\begin{array}{l}0.053 \dagger \\
(0.58)\end{array}$ \\
\hline \multicolumn{5}{|l|}{$6<$ Tenure $\leq 10$} \\
\hline years & $\begin{array}{c}0.107 \\
(3.56)^{* *}\end{array}$ & $\begin{array}{c}0.048 \\
(0.85)\end{array}$ & $\begin{array}{c}0.050 \\
(1.59)\end{array}$ & $\begin{array}{c}0.046 \\
(0.50)\end{array}$ \\
\hline \multirow[t]{2}{*}{ Tenure $>10$ years } & -0.037 & 0.119 & 0.088 & 0.140 \\
\hline & $(0.79)$ & $(1.47)$ & $(3.43)^{* *}$ & $(1.76)^{*}$ \\
\hline \multirow[t]{2}{*}{ LF Experience } & 0.037 & 0.032 & 0.005 & -0.002 \\
\hline & $(10.64)^{* * *}$ & $(5.06)^{* *}$ & $(2.18)^{*}$ & $(0.21)$ \\
\hline \multirow[t]{2}{*}{ Constant } & 3.992 & 5.660 & 4.535 & 5.336 \\
\hline & $(12.79)^{* *}$ & $(11.58)^{* *}$ & $(18.18)^{* *}$ & $(6.11)^{* *}$ \\
\hline \multirow[t]{2}{*}{ Observations } & 2635 & 404 & 3319 & 552 \\
\hline & Workers $\mathrm{v}$ & wer than 16 & education & \\
\hline Tenure $\leq 2$ years & $\begin{array}{l}-0.115 \\
(11.09)^{* *}\end{array}$ & $\begin{array}{l}-0.145 \\
(4.59)^{* *}\end{array}$ & $\begin{array}{l}-0.053 \\
(3.35)^{* *}\end{array}$ & $\begin{array}{c}-0.044 \\
(0.92)\end{array}$ \\
\hline \multirow{2}{*}{$\begin{array}{l}6<\text { Tenure } \leq 10 \\
\text { years }\end{array}$} & & & & \\
\hline & $\begin{array}{l}0.099 \\
(6.57)^{* * *}\end{array}$ & $\begin{array}{r}0.027 \\
(0.66)\end{array}$ & $\begin{array}{l}0.073 \\
(4.13)^{* * *}\end{array}$ & $\begin{array}{c}0.091 \\
(1.81)^{*}\end{array}$ \\
\hline Tenure $>10$ years & $\begin{array}{l}0.116 \\
(6.28)^{* * *}\end{array}$ & $\begin{array}{c}-0.004 \\
(0.07)\end{array}$ & $\begin{array}{c}0.209 \\
(14.99)^{* *}\end{array}$ & $\begin{array}{l}0.127 \\
(3.24)^{* *}\end{array}$ \\
\hline LF Experience & $\begin{array}{c}0.021 \\
(16.76)^{* *}\end{array}$ & $\begin{array}{c}0.033 \\
(8.30)^{* *}\end{array}$ & $\begin{array}{l}-0.007 \\
(5.09)^{* *}\end{array}$ & $\begin{array}{c}0.001 \\
(0.42)\end{array}$ \\
\hline Constant & $\begin{array}{c}4.459 \\
(56.45)^{* *}\end{array}$ & $\begin{array}{c}4.378 \\
(12.07)^{* *}\end{array}$ & $\begin{array}{c}5.325 \\
(59.02)^{* *}\end{array}$ & $\begin{array}{c}5.001 \\
(22.45)^{* *}\end{array}$ \\
\hline Observations & 9005 & 692 & 7940 & 880 \\
\hline
\end{tabular}

Note. Absolute values of $z$ statistics are in parentheses.

* Significant at $5 \%$ level.

** Significant at $1 \%$ level.

$\dagger$ Difference in the Tenure $\leq 2$ years effect or the LF experience effect between high-tech and other industries is significant at the $5 \%$ level.

employer. To allow for the possibility that the effects of tenure are not linear, we measured tenure with a set of dummy variables for the following categories: $0-2.0,2-6.0,6-10.0$, and greater than 10 years. These categories allow us to distinguish the effects on earnings of low tenure, moderate levels of tenure, and high levels of tenure; and (5) years of education (note that in addition we divided the sample on the basis of whether the respondent had completed 16 years of school).

We present coefficients from the censored normal regression procedure in Tables 1-3. We focus our attention on the contrast between low tenure (which we 
TABLE 2

Trends in the Effects of Tenure and Experience for U.S. Men with at Least 16 Years of Education, Censored Normal Regression Model

\begin{tabular}{|c|c|c|c|c|c|}
\hline & 1983 & 1987 & 1991 & 1996 & 1998 \\
\hline \multicolumn{6}{|c|}{ Men 35 years old or younger } \\
\hline Tenure $\leq 2$ years & $\begin{array}{l}-0.128 \dagger \\
(3.53)^{* *}\end{array}$ & $\begin{array}{c}-0.189 \dagger \\
(4.52)^{* *}\end{array}$ & $\begin{array}{c}-0.061 \dagger \\
(1.47)\end{array}$ & $\begin{array}{c}-0.115 \dagger \\
(1.88)^{*}\end{array}$ & $\begin{array}{l}0.000 \dagger \\
(0.00)\end{array}$ \\
\hline $\begin{array}{l}6<\text { Tenure } \leq 10 \\
\text { years }\end{array}$ & $\begin{array}{c}0.107 \\
(2.11)^{*}\end{array}$ & $\begin{array}{c}0.046 \\
(0.83)\end{array}$ & $\begin{array}{c}0.121 \\
(2.14)^{*}\end{array}$ & $\begin{array}{c}0.169 \\
(1.94)^{*}\end{array}$ & $\begin{array}{c}0.066 \\
(0.98)\end{array}$ \\
\hline Tenure $>10$ years & $\begin{array}{c}-0.040 \\
(0.53)\end{array}$ & $\begin{array}{r}-0.049 \\
(0.55)\end{array}$ & $\begin{array}{c}0.104 \\
(1.39)\end{array}$ & $\begin{array}{l}-0.513 \\
(3.08)^{* *} *\end{array}$ & $\begin{array}{c}0.136 \\
(1.18)\end{array}$ \\
\hline LF Experience & $\begin{array}{c}0.029 \dagger \\
(6.30)^{* *}\end{array}$ & $\begin{array}{c}0.030 \dagger \\
(5.51)^{* *}\end{array}$ & $\begin{array}{c}0.031 \dagger \\
(5.52)^{* *}\end{array}$ & $\begin{array}{c}0.043 \dagger \\
(5.19)^{* *}\end{array}$ & $\begin{array}{c}0.039 \dagger \\
(6.18)^{* *}\end{array}$ \\
\hline Constant & $\begin{array}{c}4.779 \\
(15.44)^{* *}\end{array}$ & $\begin{array}{c}4.589 \\
(12.89)^{* *}\end{array}$ & $\begin{array}{c}4.687 \\
(13.43)^{* *}\end{array}$ & $\begin{array}{l}3.667 \\
(4.94)^{* *}\end{array}$ & $\begin{array}{l}3.406 \\
(6.13)^{* *}\end{array}$ \\
\hline Observations & 778 & 704 & 614 & 453 & 490 \\
\hline \multicolumn{6}{|c|}{ Men between 35 and 55 years old } \\
\hline Tenure $\leq 2$ years & $\begin{array}{l}-0.162 \\
(2.72)^{* *}\end{array}$ & $\begin{array}{c}-0.130 \\
(2.08)^{*}\end{array}$ & $\begin{array}{l}-0.168 \\
(3.49)^{* *}\end{array}$ & $\begin{array}{c}-0.094 \\
(1.49)\end{array}$ & $\begin{array}{c}-0.038 \\
(0.46)\end{array}$ \\
\hline $\begin{array}{l}6<\text { Tenure } \leq 10 \\
\text { years }\end{array}$ & $\begin{array}{c}-0.008 \\
(0.13)\end{array}$ & $\begin{array}{r}0.010 \\
(0.16)\end{array}$ & $\begin{array}{c}0.056 \\
(1.04)\end{array}$ & $\begin{array}{r}0.057 \\
(0.91)\end{array}$ & $\begin{array}{r}0.117 \\
(1.30)\end{array}$ \\
\hline Tenure $>10$ years & $\begin{array}{r}0.066 \\
(1.27)\end{array}$ & $\begin{array}{l}0.056 \\
(1.05)\end{array}$ & $\begin{array}{r}0.062 \\
(1.50)\end{array}$ & $\begin{array}{c}0.122 \\
(2.28)^{*}\end{array}$ & $\begin{array}{c}0.166 \\
(2.29)^{*}\end{array}$ \\
\hline LF Experience & $\begin{array}{r}0.005 \\
(1.46)\end{array}$ & $\begin{array}{r}0.000 \\
(0.06)\end{array}$ & $\begin{array}{c}0.005 \\
(1.78)^{*}\end{array}$ & $\begin{array}{c}0.006 \\
(1.69)^{*}\end{array}$ & $\begin{array}{c}0.006 \\
(1.17)\end{array}$ \\
\hline Constant & $\begin{array}{c}5.506 \\
(14.81)^{* *}\end{array}$ & $\begin{array}{c}4.878 \\
(13.47)^{* *}\end{array}$ & $\begin{array}{c}4.310 \\
(14.99)^{* *}\end{array}$ & $\begin{array}{l}4.262 \\
(9.00)^{* *}\end{array}$ & $\begin{array}{l}3.436 \\
(5.42)^{* * *}\end{array}$ \\
\hline Observations & 631 & 760 & 891 & 788 & 801 \\
\hline
\end{tabular}

Note. Absolute values of $z$ statistics are in parentheses.

* Significant at $5 \%$ level.

** Significant at $1 \%$ level.

$\dagger$ Linear interaction between calendar time and the coefficient for the indicated row variable is significant at the $5 \%$ level.

operationalize as $0-2.0$ years of tenure) and moderate tenure (2-6.0 years of tenure). The earnings of workers with substantial levels of tenure are a function not only of current market conditions, but also of market conditions in the (possibly distant) past (e.g., the 1996 earnings of workers with 10 years of tenure depend upon the accumulated compensation policies for American firms going back to 1986, the year these workers were hired by the company they still worked for in 1996). The change in earnings for workers in the first few years of tenure is a better measure of current compensation policies.

Table 1 shows the coefficients for tenure and for labor force experience as well 
TABLE 3

Trends in the Effects of Tenure and Experience for U.S. Men with Fewer Than 16 Years of Education, Censored Normal Regression Model

\begin{tabular}{|c|c|c|c|c|c|}
\hline & 1983 & 1987 & 1991 & 1996 & 1998 \\
\hline \multicolumn{6}{|c|}{ Men 35 Years Old or Younger } \\
\hline Tenure $\leq 2$ years & $\begin{array}{l}-0.136 \dagger \\
(7.17)^{* *}\end{array}$ & $\begin{array}{l}-0.196 \dagger \\
(9.66)^{* *}\end{array}$ & $\begin{array}{l}-0.112 \dagger \\
(5.53)^{* *}\end{array}$ & $\begin{array}{c}-0.030 \dagger \\
(1.06)\end{array}$ & $\begin{array}{l}-0.075 \dagger \\
(2.76)^{* *}\end{array}$ \\
\hline $\begin{array}{l}6<\text { Tenure } \leq 10 \\
\text { years }\end{array}$ & $\begin{array}{l}0.089 \\
(3.29)^{* *}\end{array}$ & $\begin{array}{l}0.043 \\
(1.57)\end{array}$ & $\begin{array}{l}0.123 \\
(4.05)^{* *}\end{array}$ & $\begin{array}{l}0.187 \\
(4.55)^{* *}\end{array}$ & $\begin{array}{r}0.052 \\
(1.31)\end{array}$ \\
\hline Tenure $>10$ years & $\begin{array}{r}0.057 \\
(1.61)\end{array}$ & $\begin{array}{r}0.025 \\
(0.70)\end{array}$ & $\begin{array}{l}0.090 \\
(2.75)^{* * *}\end{array}$ & $\begin{array}{l}0.213 \\
(4.46)^{* * *}\end{array}$ & $\begin{array}{l}0.205 \\
(3.87)^{* * *}\end{array}$ \\
\hline LF Experience & $\begin{array}{c}0.028 \\
(15.01)^{* *}\end{array}$ & $\begin{array}{c}0.033 \\
(16.78)^{* *}\end{array}$ & $\begin{array}{c}0.031 \\
(15.65)^{* *}\end{array}$ & $\begin{array}{c}0.032 \\
(11.86)^{* *}\end{array}$ & $\begin{array}{c}0.028 \\
(10.73)^{* *}\end{array}$ \\
\hline Constant & $\begin{array}{c}4.609 \\
(67.82)^{* *}\end{array}$ & $\begin{array}{c}4.468 \\
(63.44)^{* *}\end{array}$ & $\begin{array}{c}4.304 \\
(57.55)^{* *}\end{array}$ & $\begin{array}{c}4.163 \\
(39.00)^{* *}\end{array}$ & $\begin{array}{c}4.255 \\
(44.31)^{* * *}\end{array}$ \\
\hline Observations & 2325 & 2401 & 2154 & 1378 & 1439 \\
\hline \multicolumn{6}{|c|}{ Men between 35 and 55 years old } \\
\hline Tenure $\leq 2$ years & $\begin{array}{c}-0.047 \\
(1.50)\end{array}$ & $\begin{array}{c}-0.062 \\
(1.93)^{*}\end{array}$ & $\begin{array}{l}-0.086 \\
(2.82)^{* *}\end{array}$ & $\begin{array}{r}-0.031 \\
(0.84)\end{array}$ & $\begin{array}{c}-0.030 \\
(0.81)\end{array}$ \\
\hline $\begin{array}{l}6<\text { Tenure } \leq 10 \\
\text { years }\end{array}$ & $\begin{array}{c}0.030 \\
(0.87)\end{array}$ & $\begin{array}{c}0.087 \\
(2.42)^{* *}\end{array}$ & $\begin{array}{r}0.047 \\
(1.32)\end{array}$ & $\begin{array}{c}0.095 \\
(2.42)^{* *}\end{array}$ & $\begin{array}{c}0.126 \\
(3.01)^{* *}\end{array}$ \\
\hline Tenure $>10$ years & $\begin{array}{c}0.153 \\
(5.69)^{* *}\end{array}$ & $\begin{array}{l}0.207 \\
(7.48)^{* *}\end{array}$ & $\begin{array}{l}0.187 \\
(6.93)^{* *}\end{array}$ & $\begin{array}{l}0.251 \\
(7.94)^{* *}\end{array}$ & $\begin{array}{l}0.263 \\
(7.70)^{* *}\end{array}$ \\
\hline LF Experience & $\begin{array}{l}0.002 \\
(1.22)\end{array}$ & $\begin{array}{c}0.004 \\
(2.26)^{*}\end{array}$ & $\begin{array}{c}-0.001 \\
(0.78)\end{array}$ & $\begin{array}{c}-0.001 \\
(0.55)\end{array}$ & $\begin{array}{c}0.004 \\
(1.82)^{*}\end{array}$ \\
\hline Constant & $\begin{array}{c}4.980 \\
(57.14)^{* *}\end{array}$ & $\begin{array}{c}4.777 \\
(48.53)^{* *}\end{array}$ & $\begin{array}{c}4.890 \\
(52.15)^{* *}\end{array}$ & $\begin{array}{c}4.875 \\
(42.49)^{* *}\end{array}$ & $\begin{array}{c}4.659 \\
(38.50)^{* *}\end{array}$ \\
\hline Observations & 1764 & 1850 & 1908 & 1533 & 1719 \\
\hline
\end{tabular}

Note. Absolute values of $z$ statistics are in parentheses

* Significant at $5 \%$ level.

** Significant at $1 \%$ level.

$\dagger$ Linear interaction between calendar time and the coefficient for the indicated row variable is significant at the $5 \%$ level.

as $t$ values and sample sizes for our models. ${ }^{4}$ As Table 1 shows, the earnings advantage for workers in the 3- to 5-year category is larger outside the hightechnology sector than it is in the high-technology sector for both younger and for older workers. The flatter wage-tenure profile in the high-technology sector is primarily a phenomenon that affects more highly educated workers. Statistical tests for the equality of the coefficient for tenure less than 2 years across sectors show that the difference in coefficients is statistically significant at the .05 level for older higher educated workers only. These results provide limited support for

\footnotetext{
${ }^{4}$ Note that these are a subset of the full set of regression coefficients. The full set of results, which includes the coefficients for the yearly birth cohorts, are available upon request from the authors.
} 
hypothesis 1 . Tenure profiles appear to be flatter in high-technology than in other industries, particularly for highly educated workers. Contrary to our expectations as formulated in hypothesis 2, however, the effects of general experience were more valuable in high-technology industries only for the less well educated workers among young workers (experience has only weak effects among older workers). The highly educated workers in high-technology industries were better paid than were the workers in other industries, but these differences are reflected in the larger intercept rather than in a higher rate of return to general experience.

To test hypothesis 3 about time trends in the effects of tenure on earnings, we respecified our models as follows. We combined all industries together, but this time we estimated separate models for each of the five labor force surveys in the United States using the covariates of the previous model with the addition of industry sector and (because we estimate separate models for each survey year) the exclusion of the cohort dummy variables. ${ }^{5}$ As before, we estimated these models separately for workers 35 years old or younger and then for workers between ages 35 and 55 . We further estimated separate models for workers who had completed college and for workers who had less than college completion. Tables 2 and 3 show the tenure coefficients and $t$ statistics for models that were separately estimated for groups of workers defined by age and education in order to test our above hypotheses. While workers in the 1980s gained a substantial earnings payoff to 3-6 years of tenure as compared with 1-2 years of tenure, this advantage had diminished by the middle to late 1990s. The support for our hypothesis about time trends is present for both younger and older collegeeducated workers and is also supported for younger workers who did not complete college. We then performed tests of an interaction between a linear effect of calendar time and the less than 2 years tenure category. The interaction was significant at the .05 level for the younger highly educated workers, which is consistent with our prediction. The interaction was also significant at the .05 level for less educated younger workers, which also is consistent with our prediction. The interactions were not significant for older workers. The difference in the estimated effects by age supports hypothesis 5 .

To test hypothesis 4, we compared the effects of labor market experience across the five data sets. Our results support hypothesis 4, i.e., the effects of labor force experience are stronger in the 1990s than they were in the 1980s for young, college-educated workers. The interaction of calendar time and labor force experience was statistically significant for this group at $p<.05$. Moreover, and consistent with hypothesis 4, the effects show no appreciable trend for workers with less than a college education. Also, as predicted by hypothesis 5, the trend in Table 2 is stronger for younger workers than for older workers. More highly educated workers, in other words, appear to have experienced a trade-off between returns to general experience and firm-specific experience, while lower

${ }^{5}$ Cohort and experience effects are not separately estimable in the presence of controls for education when all the earnings measures pertain to the same point in time. 
educated workers were losing the earnings gains they used to obtain from seniority even as they continued to earn relatively small increments from general experience.

The censored normal regression results, while supportive of hypotheses 1, 3, 4 , and 5, must be viewed as tentative in the absence of further statistical tests. An extensive literature argues that OLS estimates of returns to tenure may be inconsistent due to sample-selection bias. The same caveats would apply to censored normal regression analyses. These methods form estimates by comparing the earnings of workers in the sample who have different levels of tenure after adjusting for the effects of other covariates. However, when measuring the effect of a certain number of years of tenure on earnings, it must be recognized that the individuals who were hired in year $t_{0}$ and who have since accumulated $T$ years of tenure with their employer may be different from the individuals who also began working for their employer in year $t_{0}$, but who left their employer before accumulating $T$ years of tenure. The use of control variables may capture some of these differences between the movers and the stayers, but they are unlikely to capture all of them (see, e.g., Altonji and Williams, 1997, and the literature cited therein). In the following section we propose a simple method for addressing this issue.

\section{A Simple Procedure for Correcting Selection Bias}

We start with the usual specification for log-earnings where the effects of tenure and labor market experience are assumed to be linear:

$$
w_{i t}=a+b x_{i t}+c s_{i t}+u_{i}+\varepsilon_{i t},
$$

where $i$ indexes the worker and $t$ indexes time. In this specification, $w_{i t}$ represents the natural log of weekly earnings, $s_{i t}$ represents the level of tenure with the employer at time $t$, and $x_{i t}$ represents years of labor force experience. We specify $u_{i}$ as an unmeasured fixed effect that captures the unmeasured persisting characteristics of the individual that affect earnings. Our goal is to estimate $c$ and the issue is that the process of job mobility for worker $i$ is a priori nonrandom and potentially dependent on $u_{i}$. In such a case, the level of tenure, $s_{i t}$, is correlated with $u_{i}$ and the naïve OLS estimate of $c$ is biased. To be more specific, we show in the Appendix that when workers' exit rates depend mostly on their unobserved characteristics, the average $u$ for workers with $s$ years of seniority can be approximated by a linear function of $s$ as follows:

$$
u(s)=a_{0}+a_{1} s,
$$

where $a_{0}$ and $a_{1}$ are parameters that depend only on the distribution of the exit rates across workers' unobserved characteristics. When high-quality workers are more likely to exit than low quality ones, the $a_{1}$ parameter is negative and the average quality of workers with $s$ years of seniority decreases with seniority. Within this framework, the OLS regression of $w_{i t}$ on $s_{i t}$ does not provide a 
consistent estimate of $c$. Instead, OLS estimates $c+a_{1}$, which (if $a_{1}$ is negative) may dramatically underestimate the effect of tenure on earnings. Generally speaking, the sign and the magnitude of the selection bias depend on the correlation between workers' exit rates and unobserved characteristics.

To correct for this kind of bias requires information about the dynamics of seniority and/or wages. In particular, if we are able to measure tenure at time $t$ and at time $t-1$, we can estimate the true impact of tenure on wages as the impact of tenure at time $t$ on wages at time $t$ controlling for tenure at time $t-$ 1. To understand why this is the case, suppose that we aggregated workers into groups according to tenure and labor market experience at $t-1$. For each group, let us denote the average $(\log )$ wage at $t$ as $W_{g t}$, average tenure at $t$ as $S_{g t}$, labor market experience at $t$ as $X_{g t}$, and tenure at $t-1$ as $S_{g t-1}$. By construction, the average $u$ for each group at time $t$ is $U_{g t}=a_{0}+a_{1} S_{g t-1}$. Substituting this into Eq. (1) and averaging over the group yields the following:

$$
W_{g t}=a+a_{0}+b X_{g t}+c S_{g t}+a_{1} S_{g t-1}+\varepsilon_{g t} .
$$

In other words, controlling for $S_{g t-1}$ amounts to controlling for the average unobserved quality of workers within group $g$, and the grouped-data regression of $W_{g t}$ on $X_{g t}, S_{g t}$, and $S_{g t-1}$ makes it possible to identify $c$ as the regression coefficient of $S_{g t}{ }^{6}$ Equation (3) provides the actual basis for our empirical estimation of the true impact of tenure. To estimate the coefficients in this grouped-data model, we require information about employer tenure at time $t-$ 1. While this information is not present in the CPS for those workers who have changed employers since the previous year's survey (for workers who have not changed employer, tenure last year is of course 1 year less than tenure as of the survey year), we were able to impute this information using data from the Panel Study of Income Dynamics (PSID) for the years 1981-1993 (see "Imputations" in the Appendix).

The grouped-data model coefficient estimates for college-educated male workers are presented in Table 4 for the years 1983 and 1987 and in Table 5 for the years 1991, 1996, and 1998. We present results using five different imputations of tenure in the previous year for workers who have changed jobs in the past 12 months. The coefficients labeled as "average U" give the effect of the average unmeasured worker quality that derives from our joint specification of job mobility and wage determination. The coefficient for the year variable gives the effect of survey year on the average unmeasured worker quality. The other coefficients in the model are the effects of labor force experience measured in years, the effects of years of education (recall that the sample is restricted to workers who have at least 16 years of education), and the effect of working in the high-technology sector. Again we focus our attention on the contrast between the effects of two or fewer years of tenure and the effects of more than 2 up to 6 years

${ }^{6}$ A procedure such as ours that controls for unobserved quality also controls for race, ethnicity, and other unchanging characteristics of workers. 
TABLE 4

Effects of Tenure on Log-Earnings U.S. Male, Full-Time, College-Educated Workers in 1983 and 1987

\begin{tabular}{lccccc}
\hline & Impute-1 & Impute-2 & Impute-3 & Impute-4 & Impute-5 \\
\hline Tenure $\leq$ 2 years & -0.154 & -0.165 & -0.194 & -0.147 & -0.152 \\
& $(5.20)^{* *}$ & $(5.80)^{* *}$ & $(6.21)^{* *}$ & $(4.83)^{* *}$ & $(5.06)^{* *}$ \\
$6<$ Tenure $\leq 10$ years & 0.111 & 0.124 & 0.105 & 0.117 & 0.112 \\
& $(3.20)^{* *}$ & $(3.66)^{* *}$ & $(2.98)^{* *}$ & $(3.39)^{* *}$ & $(3.27)^{* *}$ \\
Tenure $>10$ years & 0.204 & 0.238 & 0.232 & 0.200 & 0.211 \\
& $(2.77)^{* *}$ & $(3.29)^{* *}$ & $(3.05)^{* *}$ & $(2.90)^{* *}$ & $(2.86)^{* *}$ \\
Average $U$ & -0.009 & -0.011 & -0.012 & -0.007 & -0.009 \\
& $(1.91)$ & $(2.42)^{*}$ & $(2.43)^{*}$ & $(1.76)$ & $(1.96)$ \\
Survey year 1987 & 0.048 & 0.049 & 0.047 & 0.047 & 0.048 \\
& $(2.48)^{*}$ & $(2.68)^{* *}$ & $(2.43)^{*}$ & $(2.43)^{*}$ & $(2.54)^{*}$ \\
Labor force experience & 0.009 & 0.009 & 0.009 & 0.008 & 0.009 \\
& $(5.83)^{* *}$ & $(6.21)^{* *}$ & $(6.19)^{* *}$ & $(5.36)^{* *}$ & $(6.03)^{* *}$ \\
High-technology sector & 0.252 & 0.234 & 0.305 & 0.247 & 0.198 \\
& $(2.82)^{* *}$ & $(2.93)^{* *}$ & $(3.90)^{* *}$ & $(2.90)^{* *}$ & $(2.41)^{*}$ \\
Years of education & 0.132 & 0.141 & 0.120 & 0.135 & 0.140 \\
$(\geq 16)$ & $(4.57)^{* *}$ & $(5.07)^{* *}$ & $(4.20)^{* *}$ & $(4.56)^{* *}$ & $(4.87)^{* *}$ \\
Constant & 3.787 & 3.647 & 4.009 & 3.738 & 3.672 \\
& $(7.85)^{* *}$ & $(7.87)^{* *}$ & $(8.45)^{* *}$ & $(7.58)^{* *}$ & $(7.70)^{* *}$ \\
Observations & 301 & 299 & 300 & 297 & 298 \\
$R^{2}$ & 0.51 & 0.55 & 0.54 & 0.52 & 0.53 \\
\hline
\end{tabular}

Note. We computed five separate imputations of tenure with the previous employer at time $t$ (assuming no mobility) for workers who in fact changed employers between $t-1$ and $t$ (see text for details). We estimated the model five times, using each of the five imputations in succession. The results of the five estimations are reported in columns Impute-1 through Impute-5. Robust $t$ statistics are in parentheses.

* Significant at $5 \%$ level.

** Significant at $1 \%$ level.

of tenure. Our results are necessarily tentative, given the gaps in available information and the inherent difficulty in distinguishing between two effects for variables that are only indirectly observable. We therefore focus not on formal statistical tests, but rather on the extent to which the pattern of results with the grouped-data model, which corrects for nonrandom selectivity, are consistent with the results we obtained from the censored normal regression estimation procedure.

The results in Tables 4 and 5 generally support the conclusions we reached based on the censored normal regression estimation, namely that the effects of tenure for college-educated workers were flatter in the 1990s than they were in the 1980s. Consistent with hypothesis 3, the earnings effect of 2-6.0 years of tenure relative to $0-2.0$ years of tenure was smaller in the $1990 \mathrm{~s}$ than in the $1980 \mathrm{~s}$ for estimates using each of the five imputations (note that all comparisons should be made between the two tables for the same data imputation). Specifically, the 
TABLE 5

Effects of Tenure on Log-Earnings U.S. Male, Full-Time, College-Educated Workers in 1991,1996 , and 1998

\begin{tabular}{lccccc}
\hline & Impute-1 & Impute-2 & Impute-3 & Impute-4 & Impute-5 \\
\hline Tenure $\leq$ 2 years & -0.125 & -0.108 & -0.093 & -0.088 & -0.131 \\
& $(3.86)^{* *}$ & $(3.27)^{* *}$ & $(2.88)^{* *}$ & $(2.45)^{*}$ & $(4.27)^{* *}$ \\
$6<$ Tenure $\leq 10$ years & 0.183 & 0.162 & 0.178 & 0.175 & 0.180 \\
& $(5.39)^{* *}$ & $(4.48)^{* *}$ & $(5.08)^{* *}$ & $(4.67)^{* *}$ & $(5.37)^{* *}$ \\
Tenure $>$ 10 years & 0.284 & 0.235 & 0.230 & 0.272 & 0.266 \\
& $(3.99)^{* *}$ & $(3.27)^{* *}$ & $(2.78)^{* *}$ & $(4.32)^{* *}$ & $(4.45)^{* *}$ \\
Average $U$ & -0.010 & -0.008 & -0.007 & -0.008 & -0.010 \\
& $(2.56)^{*}$ & $(1.89)$ & $(1.46)$ & $(2.48)^{*}$ & $(2.90)^{* *}$ \\
Survey Year 1991 & -0.020 & -0.017 & -0.012 & -0.014 & -0.020 \\
& $(0.80)$ & $(0.64)$ & $(0.40)$ & $(0.52)$ & $(0.77)$ \\
Survey Year 1996 & -0.039 & -0.039 & -0.038 & -0.034 & -0.041 \\
& $(1.40)$ & $(1.39)$ & $(1.38)$ & $(1.15)$ & $(1.45)$ \\
Labor force experience & 0.010 & 0.011 & 0.011 & 0.011 & 0.011 \\
& $(7.32)^{* *}$ & $(8.07)^{* *}$ & $(8.16)^{* *}$ & $(8.47)^{* *}$ & $(7.63)^{* *}$ \\
High-technology sector & 0.161 & 0.165 & 0.173 & 0.209 & 0.240 \\
& $(2.01)^{*}$ & $(1.41)$ & $(2.10)^{*}$ & $(2.36)^{*}$ & $(2.97)^{* *}$ \\
Years of education & 0.136 & 0.132 & 0.113 & 0.130 & 0.137 \\
$\quad \geq 16)$ & $(4.23)^{* *}$ & $(4.19)^{* *}$ & $(3.23)^{* *}$ & $(4.24)^{* *}$ & $(4.26)^{* *}$ \\
Constant & 3.762 & 3.806 & 4.103 & 3.830 & 3.742 \\
& $(7.29)^{* *}$ & $(7.55)^{* *}$ & $(7.44)^{* *}$ & $(7.69)^{* *}$ & $(7.24)^{* *}$ \\
Observations & 453 & 445 & 452 & 452 & 448 \\
$R^{2}$ & 0.41 & 0.41 & 0.42 & 0.40 & 0.43 \\
\hline
\end{tabular}

Note. We computed five separate imputations of tenure with the previous employer at time $t$ (assuming no mobility) for workers who in fact changed employers between $t-1$ and $t$ (see text for details). We estimated the model five times, using each of the five imputations in succession. The results of the five estimations are reported in columns Impute-1 through Impute-5. Robust $t$ statistics are in parentheses.

* Significant at $5 \%$ level.

** Significant at $1 \%$ level.

effect of this tenure increment in the 1990s was between 48 and $86 \%$ of its value in the 1980s across the five imputations. At the same time (and consistent with hypothesis 4), the value of additional labor force experience rose between 11 and $38 \%$ across the five imputations.

In addition, our results suggest that sample selection does not generate significant biases in the OLS estimations of trends in the returns to employer tenure. For the 1980s, our estimate of $a_{1}$, the effect of tenure on average unmeasured worker quality ("average U" in Tables 4 and 5), is negative at levels that approach statistical significance. The estimate of $a_{1}$ in the 1990s is generally similar to the estimate for the 1980s. A negative $a_{1}$ implies that unmeasured worker quality gradually decreases with tenure as, on balance, higher quality 
workers leave for better jobs elsewhere while lower quality workers stay behind. ${ }^{7}$ This pattern appears to apply both to the American labor market of the 1980s and to the American labor market of the 1990s.

\section{Discussion}

Concepts such as the "post-Fordist" firm or the "post-Fordist economy" have strong appeal because they offer a concise and clear characterization of social change. However, empirical tests of the post-Fordist theory are inherently difficult for several reasons. First, the criteria for characterizing a firm as "Fordist" or "post-Fordist" are not perfectly clear. Second, real firms do not exist in a black-and-white world; instead, they more or less closely approximate the ideal type of the post-Fordist firm. Third, the visual manifestations of post-Fordism on aggregate stratification outcomes will depend not only on structural change within organizations, but also on changes in the composition of firms along post-Fordist dimensions. Finally, data sets that have enough characteristics on firms to plausibly characterize them as "Fordist" or "post-Fordist" (e.g., the National Organization Study) lack the necessary sample size and longitudinal or retrospective information necessary for obtaining estimates of the wage-tenure relationship over time.

In this article, therefore, we have taken an alternative approach that relies on information about tenure with the employer from the yearly labor force surveys of the census bureau in order to estimate the wage-tenure relationship. Our result provides support both for our specific hypotheses and for the general argument that careers in the contemporary economy have increasingly become "externalized." Externalization is often rightly taken to be a negative characteristic because it implies diminishing employment security. Much of the research in sociology has focused on these negative aspects of externalization, as manifested either by the phenomenon of worker displacement or by the phenomenon of contingent work. But a broader view suggests that post-Fordist trends toward the weakening of internal labor markets have consequences that may be neutral or even positive in some portions of the skill distribution even as they are negative for other workers.

Our interpretation of the trends in earnings profiles has focused on shifts in the structure of internal labor markets. It is possible that changes in the relationship between supply and demand have also contributed to the trends that we observe in the data. For example, if growth in the supply of highly skilled workers has not kept pace with increases in the demand for highly skilled workers, the resulting imbalance might also lead to a flattening of the wage-tenure profiles over time. A possible role for such a microeconomic explanation should not be excluded, but Morris and Western recently noted in their survey of the literature on rising

${ }^{7}$ This pattern is consistent with what Ehrenberg, Kasper, and Rees (1991) found for the academic labor market, which is perhaps a prototypical highly educated, "post-Fordist" labor market. 
earnings inequality in the United States that "the evidence for the microeconomic argument is weak, and a number of the most recent studies have mounted compelling critiques of this argument at both the theoretical and empirical levels" (Morris and Western, 1999, p. 636). Our analysis of trends in the effects of tenure on earnings supports Morris and Western's contention that changes in the structure of firms and networks of firms are potentially a more important explanation for recent trends in the structure of earnings inequality than are changes in the supply and demand of educated labor.

Our results suggest that an increasing share of rewards may stem from general experience rather than from the salary and wage increases which are associated with "movement up the [job] ladder associated with a progressive development of knowledge or skill" (Althauser and Kalleberg, 1981). This possibility has important implications for recent work in sociology on class analysis. Sørensen (2000) argued that "rents" are an important structural basis of class position. Those workers with higher levels of skill, he argued, are in a structurally better position to extract rents via their control of rent-producing assets; this control allows them to maintain a high standard of living. Our article can be interpreted from one perspective as adding an historically specific dynamic component to such ideas. From this perspective, structural changes in the nature of production in post-Fordist society have increased the ability of highly skill workers to extract rents from employers, even as they have lowered the class position of other workers via their diminished ability to extract rents from employers. This possibility underlies the importance of studying highly skilled as well as lower skilled workers, and it also underlines the importance of careful trend analysis of market mechanisms and their effects.

Most trend analyses in sociology focus on descriptive attributes of individuals, such as their incomes or their educational attainment. In our view, trend analysis of mechanisms is critical for explaining trends in outcomes. Our article is intended to contribute to this goal. Additional research, of course, is necessary in order to further consolidate our understanding of the consequences of postFordism for earnings trajectories in particular and for stratification more generally. This research should employ multiple strategies, including the analysis of richly textured organizational survey data such as the NOS, the analysis of panel data such as the PSID, and the analysis of repeated cross-sectional data such as the CPS, which can support reliable trend analysis of stratification outcomes.

The question of post-Fordism's impact on women is particularly complex. Other strong trends in gender stratification were already at work before postFordist organizational change became prominent. Moreover, the noncontinuous character of many women's careers significantly complicates efforts to separate the effects of internal and external labor markets on career trajectories. The importance of understanding how these trends affect women, and how they affect female-dominated occupations that cannot effectively be studied in male-only samples, cannot be overstated. Further progress is to be expected, however, as 
new data become available, especially if the trend effects strengthen in response to a deepening post-Fordist transformation of the American economy.

\section{APPENDIX}

\section{A Simple Framework for Analyzing Selection Biases}

\section{Average Workers' Quality and Employer Tenure}

Let us assume that workers' probability of exiting firms depends mostly on their unobserved $u$, and let us denote these probabilities as $P_{u}$. Using this assumption, we verify that the probability of finding a $u$-type worker with $x$ years of labor market experience and $s$ years of seniority is as follows:

$$
P_{u x}(s)=P_{u}\left(1-P_{u}\right)^{s-1} \text { for } 0<s<x+1 \text { and zero otherwise. }
$$

With this notation, the average unobserved characteristics for workers with $x$ years of labor market experience and $s$ years of seniority is as follows:

$$
u_{x}(s)=\Sigma_{u \varepsilon \cup} q_{u} P_{u x}(s) u,
$$

where $U$ is the set of all possible $u$ and $q_{u}$ the share of $u$-type workers in the population. Assuming that the $P_{u}(s)$ quantities are small, we verify that $u_{x}(s)$ can be approximated by a linear function of $s$ as follows:

$$
u(s)=a_{0}+a_{1} s \text { with } a_{0}=\Sigma_{u \varepsilon U} u q_{u} P_{u} \text { and } a_{1}=-\Sigma_{u \varepsilon U} u q_{u} P^{2} u .
$$

When the exit rates for high-quality workers are higher than for low-quality workers, $u$ is positively correlated with $P_{u}$ and $a_{1}$ is negative, meaning the average quality of workers decrease with seniority. This generates biases in the OLS estimates of returns to employer tenure. If the correlation between exit rates and workers' quality increases over time, $a_{l}$ becomes more negative over time and this generates biases in the OLS estimated trends in returns to employer tenure.

\section{Imputations}

Using PSID data on male heads of households who were currently working and who had changed employers since the previous survey, we estimated a multinomial logit model of the tenure that these workers who changed employers since the previous survey would have in the current year if they had not changed employers. We estimated this model as a function of labor force experience, which is the strongest source of variation in employer tenure. We used the same four tenure categories as in our censored normal regressions. We then used the results of the multinomial logit analysis on the PSID data to impute tenure in the previous job for workers in the CPS data. We generated five separate imputations in order to assess the stability of our results. We then aggregated the CPS data into groups defined by survey year, years of labor force experience, and the tenure category ( $\leq 2,>2$ and $\leq 6,>6$ and $\leq 10$, and $>10$ years) that the worker 
would have in the current year if he worked for the same employer as last year. For each of these groups, we computed average values for the variables in the analysis. ${ }^{8}$ Because the unequal cell count introduces heteroskedasticity into the error distribution, we used weighted least squares to generate consistent estimates of the standard errors.

\section{REFERENCES}

Althauser, R. P., and Kalleberg, A. L. (1981). "Firms, occupations and the structure of labor markets: A conceptual analysis," in Sociological Perspectives on Labor Markets (I. Berg, Ed.), pp. 119-149, Academic Press, New York.

Altonji, J. G., and Williams, N. (1997). Do Wages Rise with Job Seniority? A Reassessment, NBER Working Paper No. W6010.

Amemiya, T. (1973). "Regression analysis when the dependent variable is truncated normal," Econometrica 41, 997-1016.

Bernstein, J., and Mishel, L. (1997). "Has Wage Inequality Stopped Growing?" Monthly Labor Review 120, 3-16.

Blank, R. (1998). "Contingent work in a changing labor market," in Generating Jobs: How to Increase Demand for Less-Skilled Workers (R. B. Freeman and P. Gottschalk, Eds.), pp. 258-294, Russell Sage Foundation, New York.

Block, F. (1990). Postindustrial Possibilities: A Critique of Economic Discourse, Univ. of California, Berkeley.

Burris, B. (1998). "Computerization in the Workplace," Annual Review of Sociology 24, 141-157. Diebold, F. X., Neumark, D., and Polsky, D. (1997). "Job stability in the United States," Journal of Labor Economics 15, 206-233.

DiPrete, T. A., and Forristal, J. D. (1995). "Socioeconomic change and occupational location for successive cohorts of American male and female workers," Social Science Research 24, $390-438$.

DiPrete, T. A., and McManus, P. A. (1993). "Tenure, mobility, and incumbency: Comparing observed patterns of earnings with predictions from an elaborated theory of occupational and firm labor markets," Research in Social Stratification and Mobility 12, 45-82.

Doeringer, P. B., and Piore, M. J. (1971). Internal Labor Markets and Manpower Analysis, Heath Lexington, Lexington, MA.

Ehrenberg, R., Kasper, H., and Rees, D. (1991). "Faculty turnover at American colleges and universities: Analyses of AAUP data," Economics of Education Review 10, 99-110.

Fallick, B. C. (1996). "A review of recent empirical literature on displaced workers," Industrial and Labor Relations Review 50, 5-16.

Farber, H. S. (1996). The changing face of job loss in the United States, 1981-1993, Industrial Relations Section, Working Paper No. 360, Princeton University, Princeton, NJ.

Gardner, J. M. (1995). "Worker displacement: A decade of change," Monthly Labor Review 118(4), 45-57.

Golden, L. (1996). "The expansion of temporary help employment in the US, 1982-1992: A test of alternative economic explanations," Applied-Economics. 28 1127-1141.

Golden, L. M., and Appelbaum, E. (1992). "What was driving the 1982-88 boom in temporary employment? Preference of workers or decisions and powers of employers," American Journal of Economics and Sociology 51, 473-493.

Gottschalk, P. and Moffitt, R. (1998). "Changes in Job and Earnings Instability in the Panel Study of

\footnotetext{
${ }^{8}$ In order to specify the linear effect of tenure on average worker quality [see Eq. (1)], we coded imputed tenure at the midpoint of each tenure category.
} 
Income Dynamics and the Survey of Income and Program Participation," paper presented at Sage Foundation Conference on Changes in Job Stability and Job Security.

Hadlock, P., Hecker, D., and Gannon, J. (1991). "High technology employment: Another view," Monthly Labor Review 114, 26-30.

Hodson, R. (1988). "Good jobs and bad management: How new problems evoke old solutions in high-tech setting," in Sociological and Economic Approaches to Labor Markets, edited by (P. England and G. Farkas, Eds.), pp. 247-279, Plenum, New York.

Jaeger, D. A., and Stevens, A. H. (2000). "Is job stability in the US falling? Reconciling trends in the current population survey and panel study of income dynamics," in On the Job: Is Long Term Employment a Thing of the Past? (D. Neumark, Ed.), pp. 31-69, Russell Sage Foundation, New York.

Johnson, G. E. (1997). "Changes in earnings inequality: The role of demand shifts," Journal of Economic Perspectives 11, 41-54.

Kalleberg, A. L., Reskin, B. F., and Hudson, K. (2000). "Bad jobs in America: Standard and non-standard employment relations and job quality in the United States," American Sociological Review 65, 256-278.

Kanter, R. (1984). "Variations in managerial career structures in high-technology firms: The impact of organizational characteristics on internal labor market patterns," in Internal Labor Markets, (P. Osterman, Ed.), pp. 109-132, MIT Press, Cambridge, MA.

Kanter, R. (1991). "The Future of Bureaucracy and Hierarchy in Organizational Theory," in Social Theory for a Changing Society, edited by Pierre (P. Bourdieu and J. Coleman, Eds.), pp. 63-86, Westview, Boulder, CO.

Lerman, R. I. (1997). "Reassessing trends in U.S. earnings inequality,” Monthly Labor Review 120, 17-25.

Luker, W. and Lyons, D. (1997). "Employment shifts in high-technology industries, 1988-96," Monthly Labor Review 120, 12-25.

McGill, D., Brown, K., Haley, J., and Schieber, S. (1996). Fundamentals of Private Pensions, Univ. of Pennsylvania Press, Philadelphia.

Morris, M., and Western, B. (1999). "Inequality in earnings at the close of the 20th century," Annual Review of Sociology 25, 623-657.

Noyelle, T. J. (1987). Beyond Industrial Dualism: Market and Job Segmentation in the New Economy, Westview Press, Boulder, CO.

Osterman, P. (1994). "How common is workplace transformation and who adopts it", Industrial and Labor Relations Review 47, 173-188.

Piore, M. J., and Sabel, C. F. (1984). The Second Industrial Divide: Possibilities for Prosperity, Basic Books, New York.

Polivka, A. E. (1996). "Data watch: The redesigned current population survey," Journal of Economic Perspectives 10(3), 169-180.

Reich, R. (1991). The Work of Nations, Vintage, New York.

Rosenfeld, R. A. (2001). "Employment flexibility in the United States: Changing and maintaining gender, class, and ethnic work relationships," in Reconfigurations of Class and Gender (J. Baxter and M. Western, Eds.), Stanford Univ. Press, Stanford, CA.

Ryscavage, P. (1995). “A surge in growing income inequality,” Monthly Labor Review 118, 51-61. Smith, V. (1997). "New forms of work organization," Annual Review of Sociology 23, 315-339.

Sørensen, A. B. (2000). "Toward a Sounder Basis for Class Analysis," American Journal of Sociology 105, 1523-1558.

Tilly, C. (1996). Half a Job: Bad and Good Part-Time Jobs in a Changing Labor Market, Temple Univ. Press, Philadelphia.

U. S. Census Bureau. (2001). Statistical Abstract of the United States, 2000, U.S. Census Bureau, Washington, DC. 